\title{
Torsion of an iatrogenic parasitic fibroid related to power morcellation for specimen retrieval
}

\author{
Deepa Maheswari Narasimhulu, Ellis Eugene, Saraf Sumit \\ Department of Obstetrics and Gynecology, Maimonides Medical Center, Brooklyn, United States
}

\begin{abstract}
Parasitic fibroids are generally diagnosed incidentally at the time of surgery performed for symptomatic uterine fibroids. Torsion of a parasitic fibroid causing severe acute onset pain is extremely rare. We report a torsed parasitic fibroid in a patient who underwent hysterectomy using power morcellation for specimen retrieval. A 40-year-old patient with a history of laparoscopic supracervical hysterectomy 8 years prior presented with severe abdominal pain. She was diagnosed with degenerating parasitic fibroids on magnetic resonance imaging and was managed conservatively. Surgery was performed 3 days later for persistent pain, and the parasitic fibroid was found to have undergone torsion. Torsed ischemic fibroids can undergo necrosis and gangrene and can potentially cause life-threatening coagulopathy and peritonitis. Awareness of this potential complication will reduce errors in diagnosis and facilitate timely management.(J Turk Ger Gynecol Assoc 2015; 16: 259-62)

Keywords: Parasitic fibroid, torsion, morcellation
\end{abstract}

Received: 06 May, 2015

Accepted: 13 September, 2015

Available Online Date: 02 November, 2015

\section{Introduction}

When a fibroid becomes partially or completely separated from the uterus and receives its main blood supply from another source, it is called a parasitic fibroid. This was first described by Kelly and Cullen in 1909. Nezhat et al. (1) described three broad categories of parasitic fibroids: (a) spontaneously developing parasitic fibroids resulting from pedunculated fibroids that have lost their connection to the uterus, (b) fibroids associated with previous uterine surgeries such as hysterectomy and myomectomy, particularly if morcellation of the uterus or fibroids was performed, (c) fibroids associated with the restriction of blood supply to the uterus (e.g., gonadotropin-releasing hormone agonists, uterine artery embolization), which may cause a pedunculated subserosal fibroid to lose its uterine blood supply and become parasitic.

Parasitic fibroids are generally diagnosed incidentally at the time of surgery for symptomatic uterine fibroids. Torsion of a parasitic fibroid causing acute onset pain is extremely rare. We report a patient with a torsed parasitic fibroid that occurred 8 years after a hysterectomy was performed using a power morcellator.

\section{Case Presentation}

A 40-year-old female presented to the emergency department of our hospital complaining of severe acute onset lower abdominal pain. She had a history of laparoscopic supracervical hysterectomy performed 8 years prior for fibroid uterus at our hospital. On reviewing her previous records, it was found that power morcellation had been used, and the pathology report showed benign fibroids. She had a low grade fever and neutrophilic leukocytosis. On examination, she had a tender mass in the pelvis.

A computed tomography (CT) scan performed in the emergency department showed a $6 \times 4.6 \times 6-\mathrm{cm}$ solid left adnexal mass and a $6 \times 10 \mathrm{~cm}$ pelvic mass. The differential diagnosis on CT scan included left adnexal mass, pelvic abscess, and fibroids. Broad-spectrum antibiotics were administered, and magnetic resonance imaging (MRI) was performed that showed a normal cervix and bilateral normal ovaries. There was a lobulated mass above the cervix measuring $9.6 \times 6.4 \times 7.4 \mathrm{~cm}$. A second smaller mass measuring $7.3 \times 5.3 \times 7.6 \mathrm{~cm}$ was found immediately cephalad and to the left of the first mass. A third mass measuring $2.7 \times 2.3 \mathrm{~cm}$ (smallest mass) was found in the right lower pelvis (Figure 1, 2). After intravenous contrast, there was only mild posterior enhancement of the largest mass, while the other two masses showed good enhancement (Figure 3). The radiologist made a diagnosis of parasitic fibroids with degeneration of the largest one based on the MRI findings.

The patient was managed conservatively using nonsteroidal anti-inflammatory drugs (NSAIDS) for pain relief. However, she continued to spike low-grade fevers, and her pain did not subside. There was also concern about malignant transformation in the fibroid. Therefore, a decision was made to perform an exploratory laparotomy and excision of pelvic masses. A small amount of blood-tinged free fluid in the pelvis was observed intraoperatively, which was sent for cytopathological analysis. There were mild adhesions between the bladder and the sigmoid colon, which were easily sepa- 


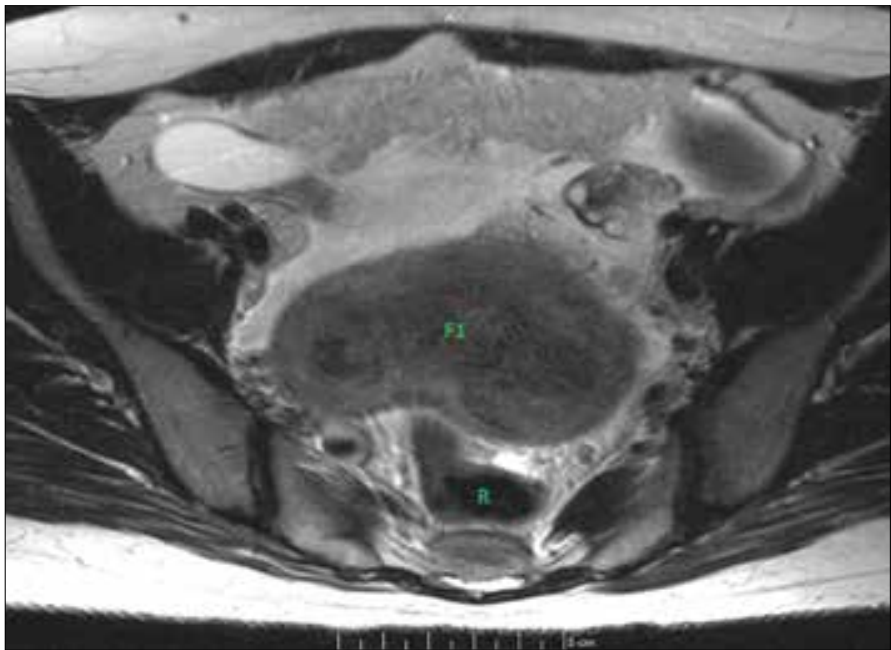

Figure 1. MRI showing a lobulated pedunculated fibroid $9 \times 6 \times 7 \mathrm{~cm}$ (F1) arising from the rectum (R)

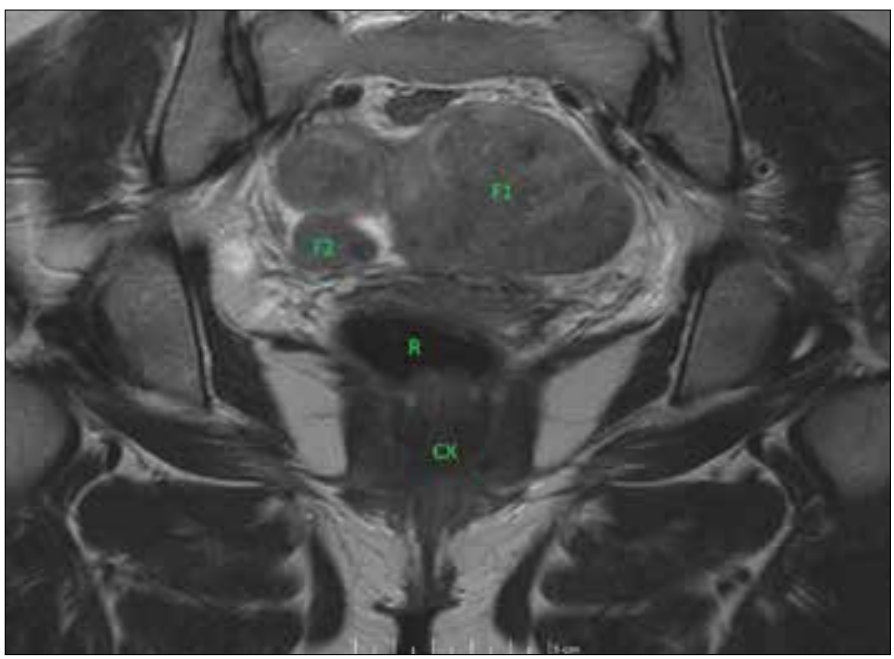

Figure 2. MRI showing a smaller fibroid $2.7 \times 2 \times 3 \mathrm{~cm}(\mathrm{~F} 2)$ above the cervix (CX) in addition to the larger fibroid (F1)

rated. After adhesiolysis, two pedunculated parasitic fibroids were identified, arising from the anterior wall of the rectum. The largest fibroid was found to be degenerated and had undergone torsion with two complete turns on its pedicle. A third parasitic fibroid was found arising from the left pelvic side wall with a thin pedicle. Both the ovaries and cervix were normal and separate from the masses. All fibroids were removed and sent for histopathological examination. The patient's postoperative recovery was uneventful, and she was discharged on the second postoperative day. The ascitic fluid cytology showed mesothelial cells, neutrophils, and lymphocytes. The pathology revealed benign fibroids with necrosis and hemorrhagic degeneration in the largest fibroid (Figure 4). The patient agreed to the publication of this report and informed consent was obtained.

\section{Discussion}

Parasitic fibroids are rare, with only a few case reports and case series reported in the literature. In the past 10 years, there

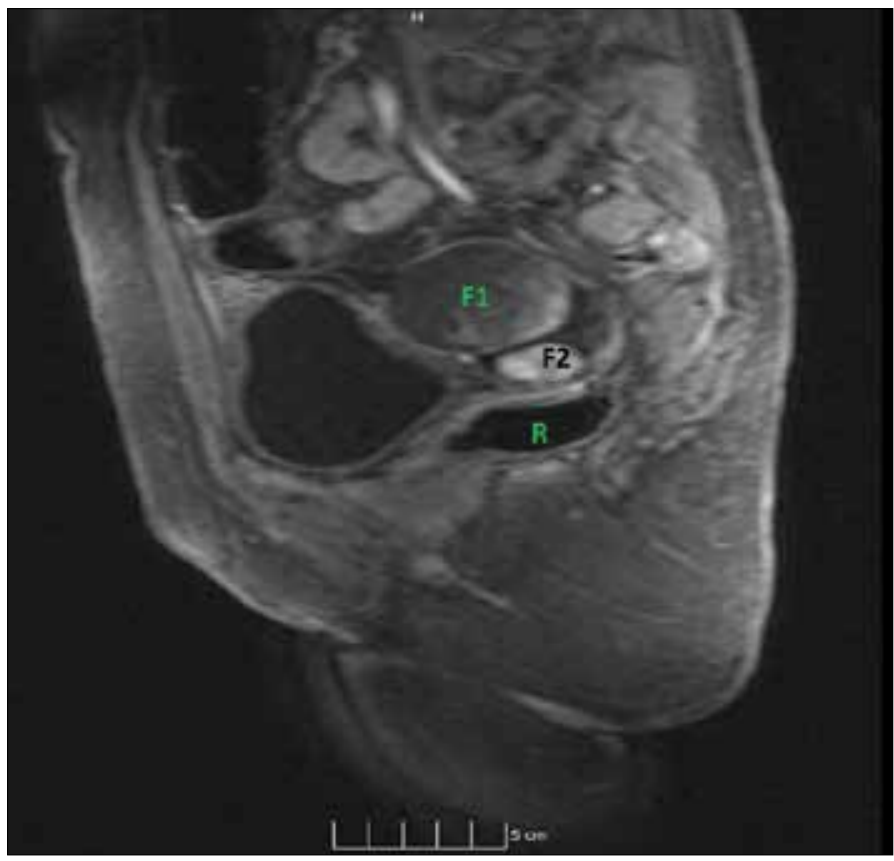

Figure 3. MRI with IV contrast (Panel C) showing an enhancement of the smaller fibroid (F2) but no enhancement of the larger fibroid (F1), suggestive of degenerative changes in the larger fibroid (F1)

has been an increase in the reports of parasitic fibroids attributable to previous surgery (iatrogenic parasitic fibroids). In a recent review of parasitic myomas after laparoscopic surgery, 48 of 53 patients were reported between 2007 and 2014 (2). Morcellation increases the possibility of leaving behind small fragments of fibroids that proceed to implant in the peritoneal cavity and form parasitic fibroids. These lesions are mostly located in the pelvis because of the gravitational movement of retained fragments. Parasitic fibroids are uncommon, whereas the loss of tissue fragments within the abdominal cavity during morcellation is presumably extremely common. Hence, it seems reasonable to hypothesize that other factors such as the exposure of fragments to steroid hormones and growth factors may contribute to the occurrence of this complication (3).

In a case series, Kho et al. (4) reported that 6 out of 12 patients with parasitic fibroids underwent laparoscopic surgery in the past that involved morcellation. Miyake et al. (5) used molecular genetic analysis to show that the parasitic fibroids resected at subsequent surgery originated from the fibroids that were morcellated during the initial surgery. The incidence of parasitic fibroids after laparoscopic surgery with morcellation is probably around $0.1 \%-1.0 \%$ (6). Parasitic fibroids are generally diagnosed incidentally at surgery for symptomatic uterine fibroids. However, there are case reports in which parasitic fibroids have been symptomatic (7-10). Torsion of a parasitic fibroid causing severe pain of acute onset is extremely rare, but there have been a few reports in the past (Table 1).

Two of these reports are from the 1990s, and both of these patients did not undergo previous surgeries; they had spontaneously formed parasitic fibroids that underwent torsion (7, 8). The other two patients had previous myomectomy: one by laparoscopy (9) and the other by laparotomy (10). All of these 
patients still had their uteri in situ at the time of presentation as opposed to our patient who had a supracervical hysterectomy in the past. Our patient also had power morcellation during the initial surgery. All patients that presented acutely, including our patient, had leukocytosis and/or neutrophilia, and two out of five patients also had fever.

On preoperative imaging, the fibroids were visualized in four out of the five patients. However, the diagnosis of parasitic fibroid was not made preoperatively in any other cases of torsion, except our patient. This is consistent with the fact that most parasitic fibroids are diagnosed incidentally at the time of surgery. The imaging modality was sonogram in three patients, while the fourth patient underwent a CT scan. Our patient underwent a CT scan and an MRI. The parasitic fibroid was thought to represent a torsed ovarian mass in one patient, a torsed pedunculated fibroid in the second, and an incidental finding in the third. The fourth patient had a sonogram, and the parasitic fibroid was not seen (Table 1). In our patient, the CT scan was not conclusive, and the diagnosis of parasitic fibroid was made on MRI. The sites of origin of the torsed fibroid in the previously reported patients were the omentum, mesentery, and broad ligament, whereas it arose from the rectum in our patient. The histopathology report in all these patients showed some evidence of infarct, necrosis, or degeneration. The ascitic fluid cytology in our patient showed neutrophils and lymphocytes that are indicative of an inflammatory response to the ischemic and necrotic fibroids.

Table 1. Torsed parasitic fibroids, comparison and review of reported cases

\begin{tabular}{|c|c|c|c|c|c|}
\hline Author & $\begin{array}{l}\text { Brieger et al. (7), } \\
1995\end{array}$ & $\begin{array}{l}\text { Yeh et al. (8), } \\
1999\end{array}$ & $\begin{array}{l}\text { Tan et al. (9), } \\
2012\end{array}$ & $\begin{array}{l}\text { Park et al. (10), } \\
2013\end{array}$ & Our patient \\
\hline Age (years) & 41 & 33 & 44 & 45 & 40 \\
\hline Previous surgery & None & None & $\begin{array}{l}\text { Laparoscopic } \\
\text { myomectomy } \\
2 \text { years ago. } \\
\text { Morcellator use } \\
\text { not specified }\end{array}$ & $\begin{array}{l}\text { Abdominal } \\
\text { myomectomy } \\
10 \text { years ago }\end{array}$ & $\begin{array}{l}\text { Laparoscopic } \\
\text { supracervical } \\
\text { hysterectomy with } \\
\text { power morcellation } \\
8 \text { years ago }\end{array}$ \\
\hline Presenting symptom & $\begin{array}{l}\text { Lower abdominal } \\
\text { pain starting } 36 \mathrm{hrs} \\
\text { before presentation }\end{array}$ & $\begin{array}{l}\text { Lower abdominal } \\
\text { pain for } 5 \text { days } \\
\text { before presentation }\end{array}$ & $\begin{array}{l}\text { Acute right } \\
\text { lower } \\
\text { abdominal } \\
\text { pain }\end{array}$ & $\begin{array}{l}\text { Pain in the right } \\
\text { lower abdomen } \\
\text { for } 2 \text { weeks } \\
\text { before } \\
\text { presentation }\end{array}$ & $\begin{array}{l}\text { Severe pain in the } \\
\text { lower abdomen for } \\
6 \mathrm{~h} \text { before } \\
\text { presentation }\end{array}$ \\
\hline Clinical findings & Neutrophilia & Leukocytosis & $\begin{array}{l}\text { Fever, } \\
\text { Neutrophilic } \\
\text { leukocytosis }\end{array}$ & None & $\begin{array}{l}\text { Fever, Neutrophilic } \\
\text { leukocytosis }\end{array}$ \\
\hline Imaging & $\begin{array}{l}\text { Ultrasound: } \\
\text { Mass in pouch of } \\
\text { douglas seen separately } \\
\text { from a normal sized } \\
\text { uterus }\end{array}$ & $\begin{array}{l}\text { Ultrasound: mass } \\
\text { seen in the upper } \\
\text { pelvis and lower } \\
\text { abdomen separate } \\
\text { from the uterus. } \\
2 \mathrm{~cm} \text { subserosal } \\
\text { uterine fibroid. } \\
\text { Small amount of } \\
\text { free fluid }\end{array}$ & $\begin{array}{l}\text { CT scan: two } \\
\text { masses seen } \\
\text { separate from } \\
\text { the uterus in } \\
\text { the lower } \\
\text { abdomen and } \\
\text { pelvis. Small } \\
\text { amount of free } \\
\text { fluid. Appendix } \\
\text { mildly dilated }\end{array}$ & $\begin{array}{l}\text { Ultrasound: } \\
\text { enlarged uterus } \\
\text { with multiple } \\
\text { intramural fibroids. } \\
\text { The parasitic } \\
\text { fibroid was not } \\
\text { seen }\end{array}$ & $\begin{array}{l}\text { MRI: three parasitic } \\
\text { fibroids, one of them } \\
\text { degenerating. Small } \\
\text { amount of free fluid }\end{array}$ \\
\hline $\begin{array}{l}\text { Pre-operative } \\
\text { diagnosis }\end{array}$ & Torsion of ovarian cyst & $\begin{array}{l}\text { Torsion of } \\
\text { pedunculated fibroid }\end{array}$ & $\begin{array}{l}\text { Acute } \\
\text { appendicitis }\end{array}$ & \begin{tabular}{l|} 
Fibroid uterus \\
with pain
\end{tabular} & $\begin{array}{l}\text { Degenerated } \\
\text { parasitic fibroid }\end{array}$ \\
\hline $\begin{array}{l}\text { Route of surgery for } \\
\text { the parasitic fibroid }\end{array}$ & $\begin{array}{l}\text { Laparoscopy, specimen } \\
\text { removal by colpotomy }\end{array}$ & Not specified & Laparotomy & $\begin{array}{l}\text { Laparoscopy } \\
\text { Power morcellation }\end{array}$ & Laparotomy \\
\hline No. of parasitic fibroids & 1 & 1 & 3 & 1 & 3 \\
\hline Origin of torsed fibroid & Omentum & Broad ligament & Omentum & Mesentery & Rectum \\
\hline $\begin{array}{l}\text { Adhesions } \\
\text { (intraoperative } \\
\text { finding) }\end{array}$ & None & None & None & $\begin{array}{l}\text { Severe adhesions } \\
\text { of torsed fibroid to } \\
\text { the omentum and } \\
\text { bowel }\end{array}$ & $\begin{array}{l}\text { Severe adhesions of } \\
\text { torsed fibroid to the } \\
\text { bladder and sigmoid } \\
\text { colon }\end{array}$ \\
\hline Pathology & $\begin{array}{l}\text { Leiomyoma with } \\
\text { necrosis and dystrophic } \\
\text { calcification }\end{array}$ & $\begin{array}{l}\text { Leiomyoma with } \\
\text { hemorrhagic } \\
\text { infarction }\end{array}$ & $\begin{array}{l}\text { Leiomyoma with } \\
\text { areas of edema, } \\
\text { hemorrhage, } \\
\text { and infarction }\end{array}$ & $\begin{array}{l}\text { Leiomyoma } \\
\text { with infarction }\end{array}$ & $\begin{array}{l}\text { Leiomyoma with } \\
\text { hemorrhagic } \\
\text { infarction }\end{array}$ \\
\hline
\end{tabular}




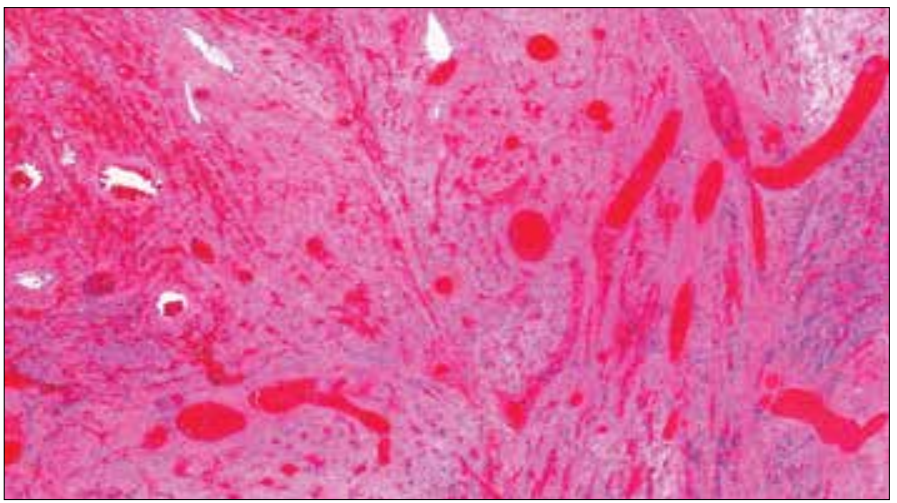

Figure 4. Histopathological examination (Hematoxylin and eosin staining, 40x) revealed leiomyoma with hemorrhagic degeneration in the larger one that was found to be torsed intraoperatively

Our patient is the first reported case of post hysterectomy torsed iatrogenic parasitic fibroid with a documented use of a power morcellator at initial surgery. The site of origin of the fibroid, the rectum, is also unusual, and the other authors reported parasitic fibroids arising from the omentum and mesentery, which are more likely to undergo torsion. Early diagnosis of torsion is important because ischemia or necrosis can cause consumptive coagulopathy, gangrene, and peritonitis, which can be life threatening.

There have been reports of the spread of endometriosis, adenomyomas, cervical tissue, endometrial cancer, and uterine sarcoma in the abdominal cavity after morcellation. The major concern is the possible spread of occult malignancy, and the United States Food and Drug Administration has released a safety communication discouraging the use of power morcellators. However, parasitic fibroids have been reported after abdominal hysterectomy and abdominal myomectomy (4). Hence, restricting the use of power morcellation will not eliminate iatrogenic parasitic fibroids.

To conclude, iatrogenic parasitic fibroids are rare complications after previous uterine surgery, and an acute presentation due to torsion is even rarer. Most of these patients present with severe pain and peritoneal signs. Low-grade fever and leukocytosis may be present. MRI is the best tool to evaluate these lesions. Awareness of this potential complication will reduce the delay in diagnosis and facilitate appropriate management.
Ethics Committee Approval: N/A.

Informed Consent: Written informed consent was obtained from patient who participated in this case.

Peer-review: Externally peer-reviewed.

Author Contributions: Concept - D.M.N., E.E., S.S; Design - D.M.N., E.E., S.S.; Supervision - E.E., S.S.; Resource - D.M.N.; Materials D.M.N.; Data Collection and/or Processing - D.M.N.; Analysis and/ or Interpretation - D.M.N., E.E., S.S.; Literature Search - D.M.N., E.E., S.S.; Writing - D.M.N., E.E., S.S.; Critical Reviews - E.E., S.S.

Conflict of Interest: No conflict of interest was declared by the authors.

Financial Disclosure: The authors declared that this study has received no financial support.

\section{References}

1. Nezhat $\mathrm{C}$, Kho $\mathrm{K}$. Iatrogenic myomas: new class of myomas? J Minim Invasive Gynecol 2010; 17: 544-50. [CrossRef]

2. Erenel H, Temizkan O, Mathyk BA, Karataş S. Parasitic myoma after laparoscopic surgery: a mini-review. J Turk Ger Gynecol Assoc 2015; 16: 181-6. [CrossRef]

3. Cucinella G, Granese R, Calagna G, Somigliana E, Perino A. Parasitic myomas after laparoscopic surgery: an emerging complication in the use of morcellator? Description of four cases. Fertil Steril 2011; 96: e90-6. [CrossRef]

4. Miyake T, Enomoto T, Ueda Y, Ikuma K, Morii E, Matsuzaki S, Murata Y. A case of disseminated peritoneal leiomyomatosis developing after laparoscope-assisted myomectomy. Gynecol Obstet Invest 2009; 67: 96-102. [CrossRef]

5. Leren V, Langebrekke A, Qvigstad E. Parasitic leiomyomas after laparoscopic surgery with morcellation. Acta Obstet Gynecol Scand 2012; 91: 1233-6. [CrossRef]

6. Moon HS, Koo JS, Park SH, Park GS, Choi JG, Kim SG. Parasitic leiomyoma in the abdominal wall after laparoscopic myomectomy. Fertil Steril 2008; 90: 1201.e1-2. [CrossRef]

7. Brieger GM, MacGibbon AL, Peat BP. Torsion of a parasitic fibroid. Aust N Z J Obstet Gynaecol 1995; 35: 224-5. [CrossRef]

8. Yeh HC, Kaplan M, Deligdisch L. Parasitic and pedunculated leiomyomas: ultrasonographic features. J Ultrasound Med 1999; 18: 789-94.

9. Tan CH, Ho BC, Shelat V, Tan CH. Leiomyomatosis peritonealis disseminata presenting as omental torsion. Singapore Med J 2012; 53: e71-3.

10. Park DS, Shim JY, Seong SJ, Jung YW. Torsion of parasitic myoma in the mesentery after myomectomy. Eur J Obstet Gynecol Reprod Biol 2013; 169: 414-5. [CrossRef] 